\title{
ANALISIS DAN PERANCANGAN SISTEM ADMINISTRASI DAN TRANSAKSI BERBASIS CLIENT SERVER
}

\author{
Sofiansyah Fadli ${ }^{1}$, Khairul Imtihan ${ }^{2}$ \\ ${ }_{1}^{1}$ Teknik Informatika, STMIK Lombok \\ ${ }^{2}$ Sistem Informasi, STMIK Lombok \\ Jln. Basuki Rahmat No.105 Praya Lombok Tengah 83511 \\ sofiansyah182@gmail.com¹ khairulimtihan31@gmail.com² $^{2}$
}

\begin{abstract}
Almost all areas of business take advantage of computer technology as a medium of information to obtain information quickly and accurately. Daffa fitnes is one of the fitness centers that have not utilized computer technology, to manage data and provide information for members or visitors who use services on Daffa fitnes. All process activities are done manually, all data written on a plain paper, of course very high risk of loss or damage of data. In the implementation of application systems using Borland Delphi 7 programming for interface design, while for data storage using MySql database and components MyOdbc Connector as a liaison to spread data on server and client computers. It is expected that this system becomes an effective media in the management of administrative data and transactions, with the utilization of client server-based system on the application so as to facilitate the officer in managing the data in accordance with its part. This system is very feasible to be used as a medium to manage data to minimize the occurrence of errors and simplify the maintenance of data.
\end{abstract}

Keywords : System Analysis, System Design, Administration and Transaction, Client Server

\begin{abstract}
Abstrak
Hampir semua bidang usaha atau bisnis memanfaatkan teknologi komputer sebagai media informasi untuk memperoleh informasi yang cepat dan akurat. Daffa fitnes adalah salah satu pusat kebugaran yang belum memanfaatkan teknologi komputer, untuk mengelola data dan pemberian informasi bagi anggota atau pengunjung yang memakai pelayanan jasa pada Daffa fitnes. Semua proses kegiatan dilakukan secara manual, semua data ditulis pada sebuah kertas biasa, tentunya sangat tinggi resiko terjadinya kehilangan maupun rusaknya data. Pada implementasi sistem aplikasi menggunakan pemrograman Borland Delphi 7 untuk desain tampilan antarmuka, sedangkan untuk penyimpanan data menggunakan database MySql dan komponen MyOdbc Connector sebagai penghubung untuk menyebarkan data pada komputer server dan client. Diharapkan sistem ini menjadi media yang efektif dalam pengelolaan data administrasi dan transaksi, dengan pemanfaatan sistem yang berbasis client server pada aplikasi sehingga mempermudah petugas dalam mengelola data sesuai dengan bagiannya. Sistem ini sudah sangat layak untuk dimanfaatkan sebagai media untuk mengelola data untuk meminimalisir terjadinya kesalahan dan mempermudah dalam pemeliharaan data.
\end{abstract}

Kata kunci : Analisis Sistem, Perancangan Sistem, Administrasi dan Transaksi, Client Server

\section{Pendahuluan}

Contoh penggunaan Teknologi Informasi adalah untuk mengotomatisasi berbagai proses dan aktifitas yang sebelumnya dikerjakan secara manual yang mampu mengerjakan suatu pekerjaan dengan lebih baik serta mampu menyajikan data-data dan informasi yang akurat dan dibutuhkan secara cepat dan mutakhir. 
Daffa fitnes sebagai tempat sarana kebugaran telah memiliki fasilitas alat yang cukup lengkap dan intruktur yang memiliki sertifikat serta berlokasi di daerah yang strategis.

Sejak awal didirikan hingga sekarang Daffa fitnes sudah memiliki banyak pengunjung tetap baik yang berstatus sebagai member maupun non member. Namun dalam segi proses pengolahan data dan transaksinya, pada Daffa fitnes masih dilakukan secara manual atau belum terkomputerisasi, misalnya data pengunjung pada buku tamu masih ditulis pada sebuah buku biasa begitu pula dengan data membernya. Proses transaksi yang terjadi pada Daffa fitnes juga masih belum terkomputerisasi misalnya dalam pembelian barang atau alat alat olahraganya, serta penjualan barang pada Daffa fitnes hanya dicatat pada sebuah buku biasa, sehingga sangat tidak baik dalam hal pemeliharaan data dan sangat rentan untuk terjadinya sebuah kesalahan atau kecurangan dalam pembuatan laporan dan pemberian informasi.

Penulis mencoba memberikan sebuah alternatif aplikasi sistem administrasi dan transaksi. Sistem yang diperlukan adalah suatu aplikasi yang mampu mengolah data pengunjung yang ingin mendaftar menjadi member atau hanya sebagai pengunjung biasa dan tentunya membuatkan kartu anggota bagi member dan mencetak kwitansi sebagai bukti telah mendaftarkan diri sebagai member ataupun berkunjung, mengelola setiap proses transaksi yang terjadi pembelian maupun penjualan barang yang terjadi pada Daffa fitnes dan mampu menghitung besarnya pendapatan serta informasi mengenai petugas yang bertugas. Aplikasi juga dapat membuat dan menampilkan laporan data transaksi, laporan pemasukan atau pendapatan dalam harian maupun bulanan secara otomatis.

\section{Tinjuan Pustaka}

Penelitian mengenai pengolahan data transaksi juga pernah dilakukan oleh [1], mahasiswa jurusan teknik informatika Universitas Teknologi Yogyakarta, dalam penelitiannya telah mengambil judul "Pengembangan Website sebagai Media Promosi dan Penjualan Suplemen pada Fitness Centre Sinduadi". Penelitian di atas membuat suatu sistem penjualan suplemen pada Fitness Centre secara online dan sekaligus membuat sebuah website khusus untuk Fitness yang dimanfaatkan sebagai media promosi untuk memperluas jangkauan perusahaan sehingga bisa dikenal oleh masyarakat lebih banyak.

Penelitian yang dilakukan oleh [4], dengan judul perancangan sistem informasi administrasi piutang pada toko keramik panasia, dari hasil penelitian tersebut dapat diambil kesimpulankesimpulan sebagai berikut pada sistem ini datadata seperti data barang, data pelanggan, data supplier, data penjualan, dan data pembelian dicatat secara komputerisasi sehingga data dapat tersimpan dengan baik dan rapi, sistem dapat memudahkan dalam melakukan pemantauan jatuh tempo piutang pada toko keramik panasia dengan cepat dan tepat, persediaan barang pada toko keramik panasia dapat dikontrol dengan baik baik barang yang masuk dan barang yang keluar, serta dapat menyajikan laporan stok harinya, dan pada sistem ini dapat menyajikan laporan jatuh tempo piutang, laporan penjualan dan pembelian barang pada toko keramik panasia Jambi.

Penelitian dan pembuatan aplikasi tentang pengolahan data administrasi dan transaksi juga pernah dilakukan oleh mahasiswa UNIKOM Bandung [9], mahasiswa jurusan teknik informatika yang melakukan penelitian dengan judul "Sistem Informasi Pelayanan Fitness pada Red Gym Bandung" penenlitian di atas menggunakan bahasa pemrograman Delphi 7.0 sebagai desain visualnya dan Microsoft SQL Server 2008 sebagai perancangan untuk databasenya. Aplikasi yang dibangun meliputi pengolahan data administrasi yang ada pada Red Gym Bandung dibuat menjadi terkomputerisasi sehingga mempermudah dalam pemeliharaan data dan pembuatan laporan untuk setiap data administrasi yang ada. Berdasarkan ketiga penelitian tersebut maka dapat dijadikan acuan untuk membangun suatu Sistem Komputerisasi Data Administrasi dan Transaksi Berbasis Client Server pada pusat kebugaran Daffa fitnes.

Hal mendasar yang menjadi perbedaan dalam pembuatan sistem dengan refrensi adalah metode yang digunakan yaitu client server dan database yang digunkan adalah Mysql dengan bahasa pemrograman Delphi 7. Sistem yang akan di bangun tidak hanya mengacu pada proses transaksi atau penjualan saja, sistem ini juga akan menggunakan sistem yang terkomputerisasi untuk pengelolaan data customer atau member dan kegiatan administrasi yang terjadi pada Daffa fitnes dengan harapan mempermudah memproleh informasi yang ada sesuai dengan bagian dan kebutuhannya misalnya untuk bagian administrasi mengelola bagian administrasi dan memproleh informasi yang mengenai semua data administrasi atau kegiatan administrasi yang ada.

\subsection{Pengertian Analisis Sistem}

Analisis sistem (System Analysis) dapat didefinisikan sebagai penguraian dari suatu sistem informasi yang utuh ke dalam bagianbagian komponen dengan maksud untuk mengidentifikasi dan mengevaluasi permasalahan-permasalahan, kesempatankesempatan, hambatan-hambatan yang terjadi 
dan kebutuhan-kebutuhan yang diharapkan sehingga dapat diusulkan perbaikanperbaikannya. Tahap analisis sistem dilakukan setelah tahap perencanaan sistem (System Planing) dan sebelum tahap desain sisem (System Design) [8].

Tahap analisis merupakan tahap yang kritis dan sangat penting, karena kesalahan di dalam tahap ini akan menyebabkan juga kesalahan di tahap selanjutnya. Misalnya anda dihadapkan pada sustu sistem untuk menentukan seberapa jauh sistem tersebut telah mencapai sasarannya. Jika sistem ini mempunyai beberapa kelemahan, anda harus dapat menemukannya. Tugas yang diilustrasikan ini adalah yang disebut dengan analisis sistem. Istilah analisis sistem ini memang tepat, karena memang itulah yang akan dikerjakan oleh analisis sistem dalam tahap ini yaitu menganalisa sistem untuk menemukan kelemahan-kelemahan sehingga dapat diusulkan perbaikannya [8].

\subsection{Konsep Analisis dan Perancangan}

Analisis sistem (system analysis) adalah penelitian atas sistem yang telah ada dengan tujuan untuk merancang sistem baru atau diperbaharui. Kenneth E. Kendal (2010) menyatakan analisis dan perancangan sistem berupa menganalisis input data atau alir data secara sistematis, memproses atau mentranformasikan data, menyimpan data, dan menghasilkan output informasi. Selanjutnya digunakan untuk menganalisis, merancang dan mengimplementasikan peningkatan-peningkatan fungsi bisnis yang bias dicapai melalui penggunaan sistem informasi terkomputerisasi [6].

Langkah-langkah analisis sistem antara lain sebagai berikut:

1. Mengidentifikasi masalah

2. Memahami sistem kerja yang ada

3. Menganalisa sistem

4. Membuat laporan hasil analis

\subsection{Administrasi}

Cara Administrasi adalah usaha dan kegiatan yang berkenaan dengan penyelenggaraan kebijaksanaan untuk mencapai tujuan [1]. Administrasi dalam arti sempit adalah kegiatan yang meliputi: catat-mencatat, suratmenyurat, pembukuan ringan, ketik-mengetik, agenda, dan sebagainya yang bersifat teknis ketatausahaan. Administrasi dalam arti luas adalah seluruh proses kerja sama antara dua orang atau lebih dalam mencapai tujuan dengan memanfaatkan sarana prasarana tertentu secara berdaya guna dan berhasil guna.

Menurut pendapat yang lain [1] administrasi menurut arti sempit adalah kegiatan penyusunan dan pencatatan data dan informasi secara sistematis dengan tujuan untuk menyediakan keterangan serta kemudahan memperolehnya kembali secara keseluruhan dan dalam hubungan satu sama lain. Sedangkan pengertian administrasi dalam arti luas adalah kegiatan kerja sama yang dilakukan sekelompok orang berdasarkan pembagian kerja sebagaimana sumber daya untuk mencapai tujuan secara efektif dan efisien. Jadi pengertian administrasi secara luas memiliki unsur-unsur sekelompok orang, kerja sama, pembagian tugas secara terstruktur, kegiatan yang runut dalam proses, tujuan yang dicapai dan pemanfaatan sebagai sumber [1].

\subsection{Konsep Dasar Client Server}

Terdapat beberapa definisi Client-Server Menurut beberapa ahli antara lain pendapat [3], Client-Server adalah client mengirimkan permintaan ke server, server mnerjemahkan pesan, kemudian berusaha memenuhi permintaan. Client-Server adalah suatu arsitektur dimana sumberdaya server menyediakan komputasi untuk banyak komponen client. Client dan server bisa berjalan pada mesin yang sama atau berbeda, ditulis dalam berbagai bahasa dan menggunakan sistem operasi yang berbeda [2].

Adapun jenis arsitektur Client-Server dikategorikan menjadi dua bagian arsitektur diantara lainya yaitu:

1. Arsitektur 2-tier

Arsitektur Clien-Server 2-tier adalah lingkungan Clien-Server tradisional. Client biasanya terletak pada workstation yang digunakan langsung oleh user dan dibuat dengan bahasa pemrograman seperti VB, Delphi, Powerbuilder, Foxpro dan lain-lain.

Server adalah sebuah komputer yang diletakkan dibagian lain pada jaringan yang menjalankan software database sever seperti oracle, SQL Server, MySQL dan sebagainya

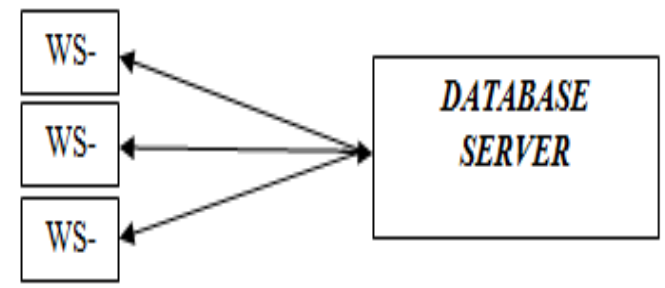

Gambar 2.1. Arsitektur 2-tier

\section{Arsitektur 3-tier}

Arsitektur Clien-Server 3-tier memecah komponen kedalam tiga kategori atau lapisan. Pada arsiterktur 3-tier terdapat lapisan tambahan middletier yang bertugas mengelola application/bussines logic, misalnya: rumus perhitungan gaji, pajak, bunga, deposito dan lainlain. Software middletier tersebut sebagai contoh: MTS (Microsoft transaction server), EJB dan lainlain. 


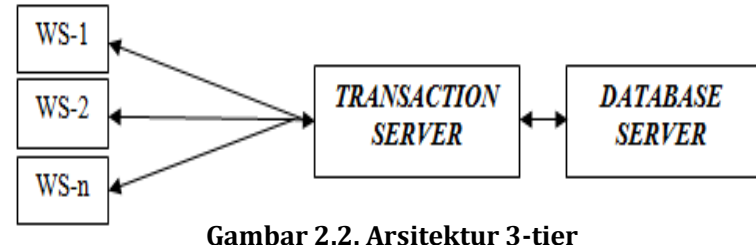

\section{Metodologi Penelitian}

\subsection{Objek Penelitian}

Penelitian ini mengambil obyek penelitian pada tempat fitnes atau pusat kebugaran Daffa Fitnes yang berlokasi pada JL. Pahlawan Renteng, No. 12, Kec. Praya, Lombok Tengah, Renteng, NTB, Kabupaten Lombok Tengah, Nusa Tenggara Barat 83514, melalui proses penelitian, wawancara dan konsultasi dengan petugas setempat, yang berhubungan dengan permasalahan yang diangkat dalam penelitian ini.

\subsection{Metode Pengambilan Data}

Metode pengambilan data dalam penelitian ini adalah sebagai berikut:

1. Pengumpulan Data

Adapun teknik pengumpulan data dalam penelitian ini adalah:

a. Observasi

Pengumpulan data yang dilakukan dengan mengadakan pengamatan dan pencatatan dengan meninjau langsung bagaimana tata kerja petugas pada pusat kebugaran atau tempat fitnes Daffa fitnes dengan tujuan mencari dan mengumpulkan data yang diperlukan sehingga akan diperoleh data yang sistematis dan sesuai dengan tujuan penelitian.

b. Metode Wawancara

Metode pengumpulan data dilakukan dengan mengajukan pertanyaan-pertanyaan atau wawancara langsung dengan para pelaku yang terdapat dalam sistem. Dalam kasus ini pihak yang diwawancara adalah petugas yang mengelola bagian proses administrasi dan transaksi yaitu pada bagian petugas yang mengelola data pengunjung dan keuangan lebih tepatnya.

c. Metode Literatur

Metode literatur yang dilakukan oleh penulis dengan berbagai cara. Cara yang pertama yaitu dengan mengumpulkan dan mempelajari bahanbahan pustaka yang berhubungan dengan permasalahan yang dipakai dan mencari referensi buku-buku karya ilmiah atau jurnal di perpustakaan untuk mendapatkan informasi mengenai sistem pengolahan data dan manajemen data transaksi.

\section{Hasil dan Pembahasan}

4.1 Analisis Data Administrasi dan Transaksi Kegiatan administrasi dan transaksi yang berjalan di tempat kebugaran Daffa fitnes selama ini belum terdapat sistem komputerisasi yang dapat mengatur dan mengelola semua proses kegiatan administrasi dan transaksi yang ada, apabila ada pengunjung yang ingin mendaftar sebagai member atau hanya sebagai pengunjung biasa atau bukan member, semua data pengunjung hanya dicatat dalam sebuah buku, begitu pula untuk kegiatan transaksi yang terjadi seperti transaksi penjualan dan pembelian semuanya masih manual belum terkomputerisasi. Apabila pengujung ingin masuk ke ruangan, pengunjung harus mengisi data diri pada buku tamu yang disediakan oleh petugas begitu pula untuk pengunjung yang berstatus sebagai member.

Untuk proses pembuatan laporannya pada tempat kebugaran Daffa fitnes, petugas akan menulis kembali dalam sebuah buku besar setiap proses transaksi yang penjualan dan pembelian yang terjadi selama satu hari yang kemudian juga akan direkap untuk data laporan bulanan, jadi akan memerlukan waktu yang lama dan menguras tenaga serta pikiran karena membutuhkan ketepatan dan ketelitian menyalin data untuk dijadikan laporan bulanan sehingga akan sangat besar kemungkinan terjadinya kesalahan dalam pengolahan data setiap kegiatan yang terjadi.

\subsection{Analisis Sistem}

Tahapan yang dibutuhkan dalam pembuatan suatu program adalah menganalisis sistem yang telah ada. Analisis terhadap suatu sistem yang berjalan bertujuan untuk mengetahui bagaimana masalah yang terdapat pada sistem tersebut, dan dapat ditemukan solusi untuk masalah yang terdapat pada sistem tersebut.

\subsection{Perancangan Sistem}

Perancangan sistem merupakan kegiatan yang sangat penting dalam menyelesaikan tugas atau masalah terutama dalam pembuatan program sehingga dapat berjalan dengan baik dan lancar. Dalam rancangan suatu sistem dapat menggunakan Diagram Konteks, Diagram Arus Data (DAD) dan Entity Relationsip Diagram (ERD).

\subsection{DAD (Diagram Alir Data)}

Diagram Alir Data merupakan suatu model logika data atau proses yang dibuat untuk menggambarkan dari mana asal data dan kemana tujuan data yang keluar dari sistem, dimana data disimpan, proses apa yang menghasilkan data tersebut dan interaksi antara data yang tersimpan dan proses yang terjadi pada data tersebut.

\subsection{ERD (Entity Relationship Diagram)}

Model Entity Relational Diagram (ERD) adalah model yang dibuat berdasarkan anggapan bahwa dunia nyata terdiri dari koleksi obyekobyek dasar yang dinamakan entitas (entity) 
serta hubungan (relationship) antara entitasentitas itu.

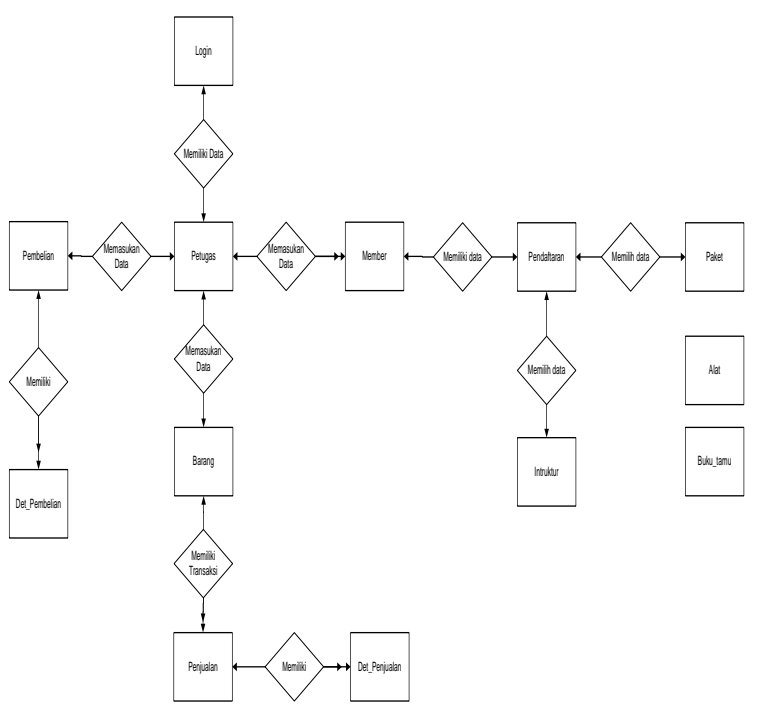

Gambar 4.1. Relasi Antar Entitas

\subsection{Diagram Konteks}

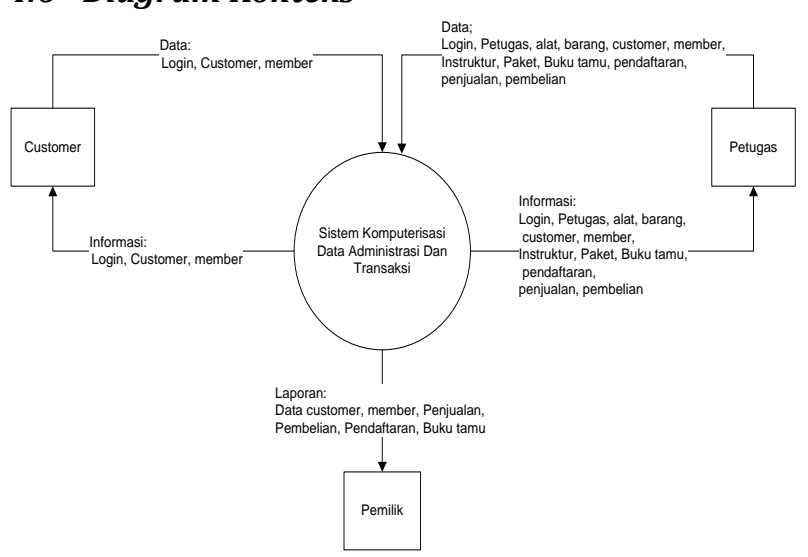

Gambar 4.2. Diagram Konteks

\subsection{Diagram Berjenjang}

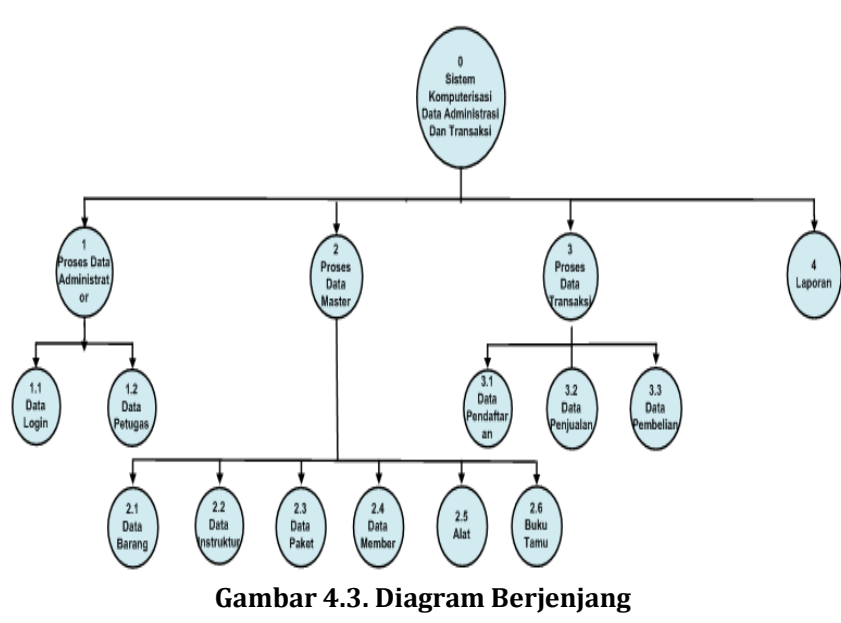

ISSN. 2620-6900 (Online) 2620-6897 (Cetak)

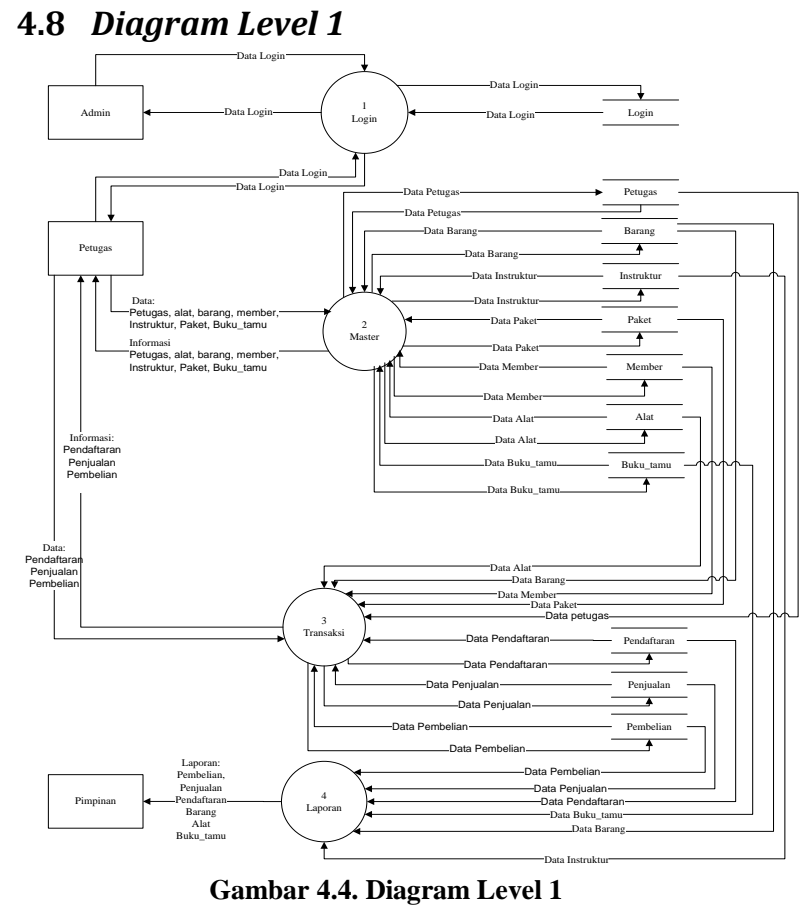

4.9 Diagram Level 2

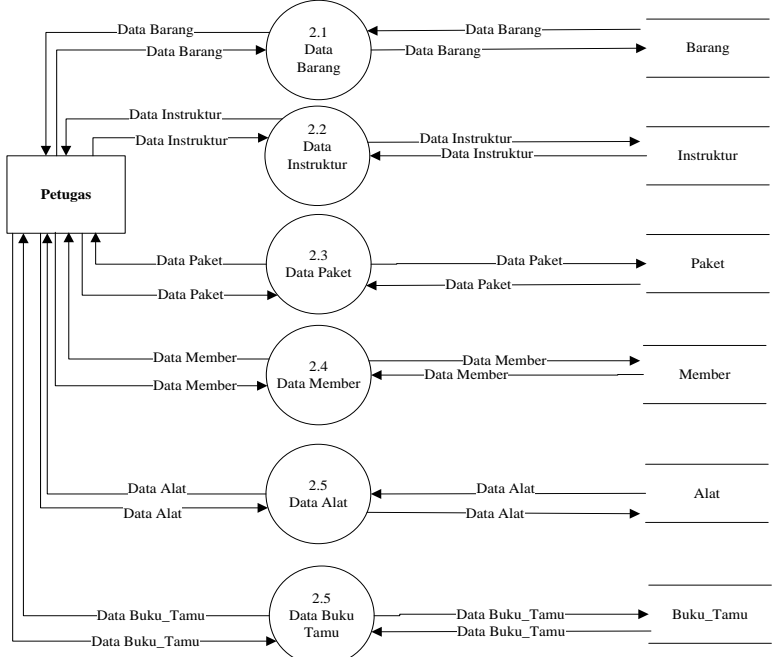

Gambar 4.5. Diagram Level 2

\subsection{Diagram Level 3}

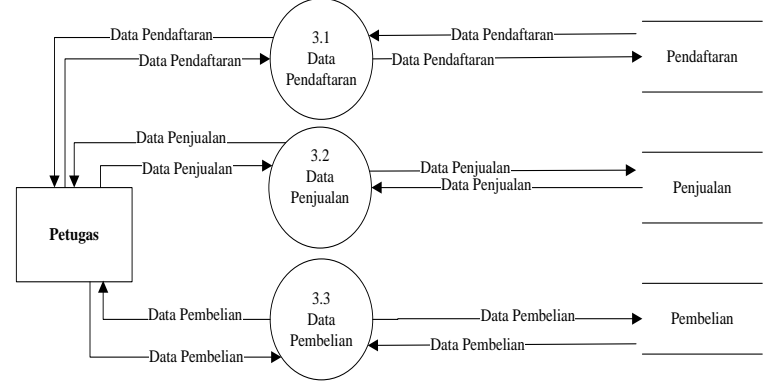

Gambar 4.6. Diagram Level 3

\subsection{Perancangan Antar Muka}

Perancangan antar muka adalah bagian dari view/tampilan program yang akan direalisasikan pada analisis dan perancangan yang sebelumnya 
telah diutarakan. Adapun perancangan antar muka perancangan ini adalah:

1. Tampilan Menu Form Utama

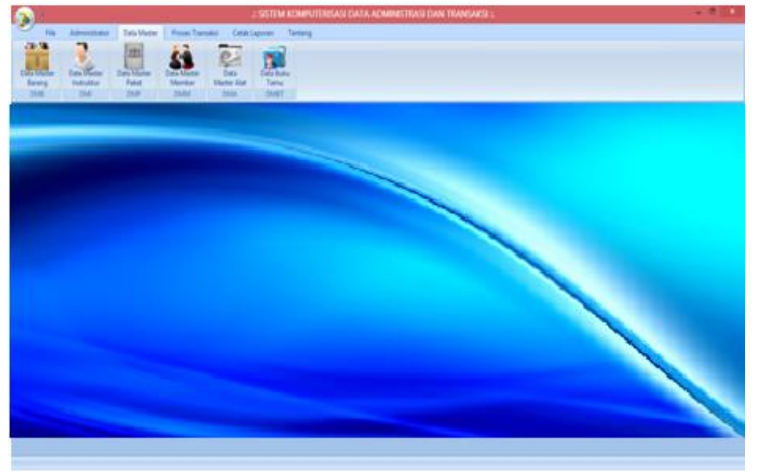

Gambar 4.7. Menu Utama

\section{Tampilan Form Data Member}

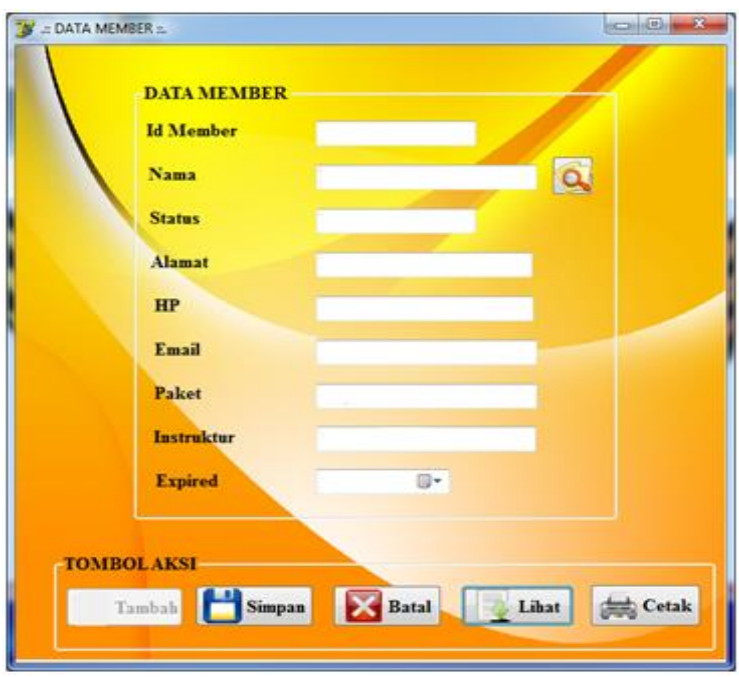

Gambar 4.8. Menu Utama

3. Tampilan Form Data Master Buku Tamu

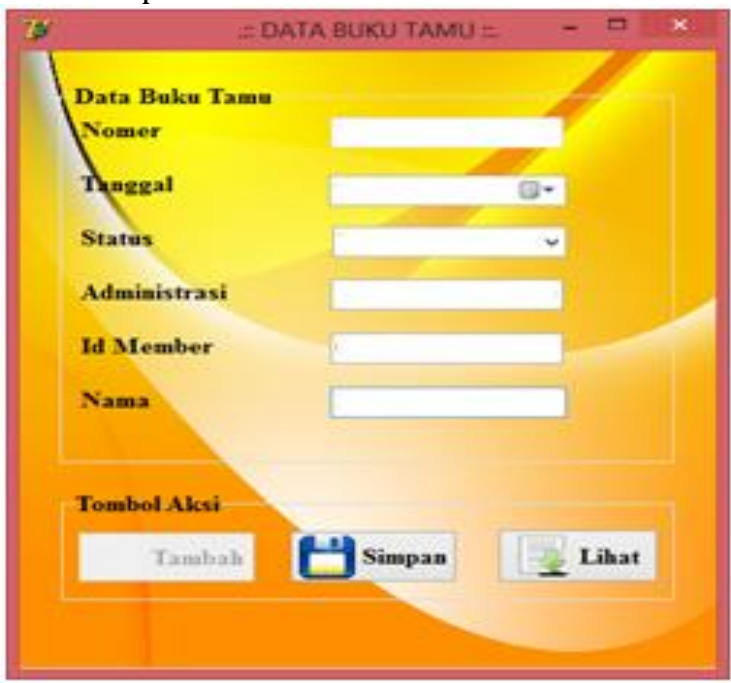

Gambar 4.9. Form Data Master Buku Tamu

4. Halaman Proses Transaksi
Pada halaman proses transaksi terdiri dari beberapa sub menu yaitu Proses transaksi pendaftaran, proses transaksi penjualan dan proses transaksi pembelian. Halaman data proses transaksi ini bisa diakses oleh petugas yang memiliki hak akses client yang memiliki tugas untuk mengelola data transaksi pembelian dan penjualan. Dimana pada sub menu Proses transaksi pendaftaran berfungsi untuk menyimpan data pendaftaran dan mencetak nota pendaftaran lebih lengkapnya mengenai penjelasan fungsi atau cara pengoperasian setiap sub menu yang terdapat pada halaman proses transaksi akan dijelaskan seperti di bawah ini.

\section{a. Tampilan Proses Transaksi Pendaftaran}

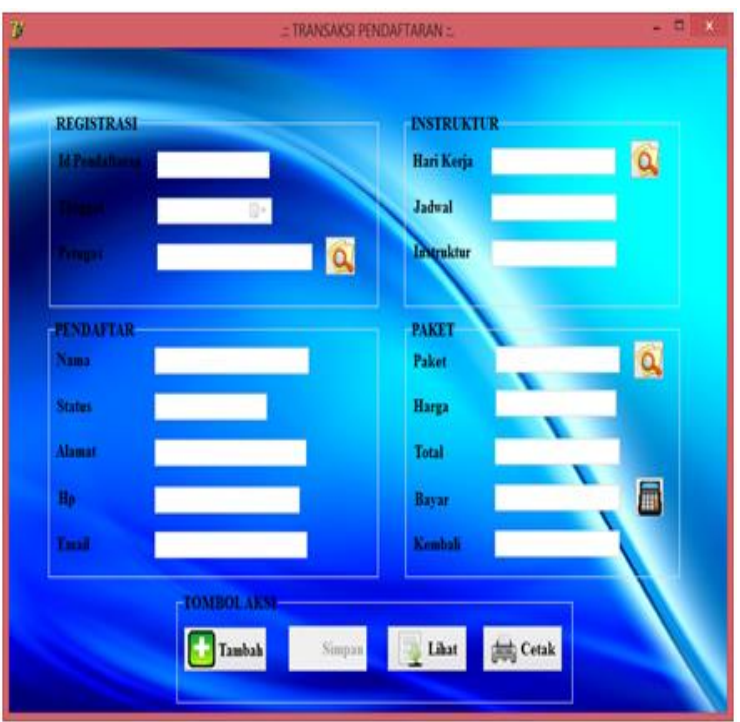

Gambar 4.10. Form Data Master Buku Tamu

b. Tampilan Form Proses Transaksi Penjualan

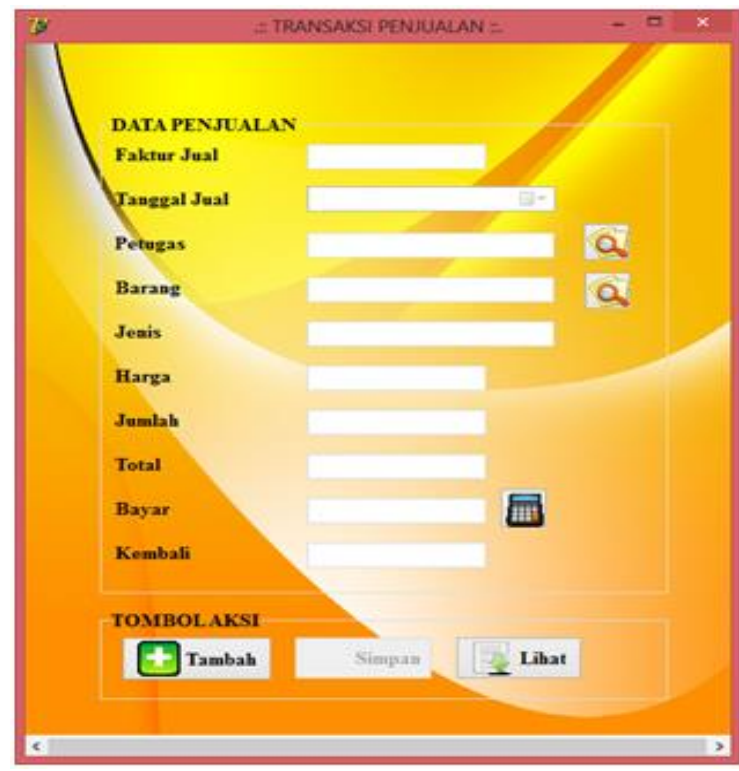

Gambar 4.11. Form Proses Transaksi Penjualan

c. Tampilan Form Proses Transaksi Pembelian 


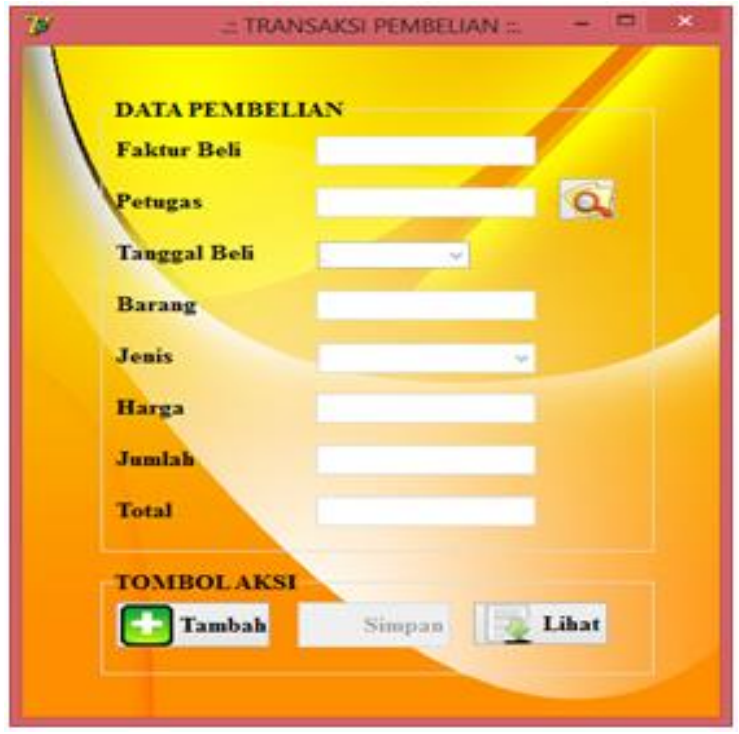

Gambar 4.12. Form Proses Transaksi Pembelian

\section{Kesimpulan dan saran}

\section{Kesimpulan}

Berdasarkan pengamatan dan penelitian yang dilakukan, maka diperoleh beberapa kesimpulan yaitu sebagai berikut:

1. Sistem ini merupakan media yang efektif dalam pengelolaan data administrasi dan transaksi, karena petugas dapat menperoleh informasi secara cepat dan akurat.

2. Sistem ini mempermudah dan mempercepat pekerjaan petugas yang mengelola bagian administrasi maupun petugas dibagian transaksi karena sudah menggunakan sistem yang terkomputerisasi terutama dalam pencarian data dan pembuatan laporan.

3. Sistem ini sudah sangat layak untuk dimanfaatkan sebagai media untuk mengelola data karena terdapatnya manajemen pengguna atau hak akses.

\section{Saran}

Berdasarkan hasil penelitian dan kesimpulan diatas maka dapat diberikan saran sebagai berikut:

1. Sistem ini dapat dikembangkan dengan menambahkan sistem buku tamu yang menggunakan barcode pada kartu member sehingga memudahkan untuk proses penginputan data pada buku tamu yang menggunakan barcode reader untuk membaca barcode pada kartu member sehingga data akan masuk secara otomatis.

2. Sistem ini kedepannya dapat dikembangakan dengan sistem database yang terdistribusi sehingga data yang diperoleh dapat terpusat dan data yang ada bisa diproses secara uptodate, apabila perusahaan membuka cabang di tempat lain.

\section{Daftar Pustaka:}

[1] Adinata, C., Yustinus., Rostianingsih, S., Setiawan, A. (2013). Perancangan dan Pembuatan Sistem Informasi Administrasi pada Bengkel Maju Jaya. Jurnal Infra. Vol 1, No 2.

[2] Blaha, M \& Premerlani, W. (1998). Objectoriented Modeling and Design for Database applications. New Jersey: Prentice-Hall.

[3] Bagye, Wire. "Implementasi Jalur Komunikasi Global System Mobile (GSM) Untuk Kontrol Robot Jarak Jauh Berbasis Mikrikontroller Atmel89S52." Jurnal Informatika dan Rekayasa Elektronik 1.1 (2018): 1-6.

[4] Fudholi, Dhomas Hatta, and Lalu Mutawalli. "An Ontology Model for Clinical Pathway Audit." 2018 4th International Conference on Science and Technology (ICST). Vol. 1. IEEE, 2018.

[5] Gallaugher, J \& Ramanathan, S. (1996). Three Critical Choice of Client Server Architecture : A Comparison of two and three tier System. Auerbach Publications : New York.

[6] Golika., Demi, D., J. (2016). Perancangan Sistem Informasi Administrasi Piutang Pada Toko Keramik Panasia. Jurnal Manajemen Sistem Informasi. Vol 1, No. 1, ISSN : 25408011.

[7] Kendall, E. Kenneth \& Julie, E., K. (2010). Analisis dan Perancangan Sistem. Edisi kelima, Jilid 1. Penerbit Indeks, Jakarta

[8] Khairul Imtihan. "Perencanaan Strategi Sistem Informasi Pendidikan Pada Sekolah Tinggi Manajemen Informatika dan Komputer (STMIK) Lombok." Bianglala Informatika 3.2 (2015).

[9] McLeod, Raymond \& George, S. (2001). Sistem Informasi Manajemen Edisi Bahasa Indonesia". Penerbit Indeks, Jakarta.

[10] Santoso, Irfan, B. (2013). Pengembangan Website sebagai Media Promosi dan Penjualan Suplemen (Study Kasus: Sinduadi Fitness Center). Universitas Teknologi Yogyakarta.

[11] Satzinger, W. John. (2007). Pengenalan Sistem Informasi Manajemen Edisi Bahasa Indonesia. Penerbit Indeks, Jakarta.

[12] Setiawati, Ubudiyah. (2013). Sistem Informasi Pelayanan Fitness (Study Kasus: Red Gym Bandung). UNIKOM Bandung.

[13] Fadli, S. (2018). Model Rapid Application Development Dalam Pengembangan Sistem Reservasi dan Penyewaan Kamar Hotel. Jurnal Informatika dan Rekayasa Elektronik (hal. 57-64). Praya: STMIK Lombok.

[14] Sunardi, S., Fadli, S. (2018). Identifikasi Masalah Penerapan Metode Agile (SCRUM) Pada Pengembangan Perangkat Lunak Di 
Perguruan Tinggi (Studi Kasus Universitas Nahdlatul Ulama Nusa Tenggara Barat). Jurnal Manajemen Informatika dan Sistem Informasi (hal. 14-18). Praya: STMIK Lombok.

[15] Fadli, S., Sunardi, S., (2018). Perancangan Sistem Dengan Metode Waterfall Pada Apotek XYZ. Jurnal Manajemen Informatika dan Sistem Informasi (hal. 29-35). Praya: STMIK Lombok.

[16] Sunardi, S., Fadli, S. (2018). Identifikasi Masalah Penerapan Metode Agile (SCRUM) Pada Pengembangan Perangkat Lunak Di Perguruan Tinggi (Studi Kasus Universitas Nahdlatul Ulama Nusa Tenggara Barat). Jurnal Manajemen Informatika dan Sistem Informasi (hal. 14-18). Praya: STMIK Lombok.
[17] Fadli, S., Sunardi, S., (2018). Perancangan Sistem Dengan Metode Waterfall Pada Apotek XYZ. Jurnal Manajemen Informatika dan Sistem Informasi (hal. 29-35). Praya: STMIK Lombok.

[18] Kalaena, L. S., \& Bagye, W. (2018). Implementasi Network Attached Storage (NAS) Menggunakan Freenas Pada STMIK Lombok. Jurnal Manajemen Informatika dan Sistem Informasi, 1(1), 6-10. 